\title{
Assessment of knowledge, attitude and practice of post-exposure prophylaxis against blood-borne viral infection among dental surgeons in a teaching hospital
}

\author{
Mercy Okoh $^{\mathrm{a}, *}$ and Birch Dauda Saheeb ${ }^{\mathrm{b}}$ \\ a Oral Pathology and Medicine Department, University of Benin Teaching Hospital, Benin City, Nigeria \\ bOral and Maxillofacial Surgery Department, University of Benin Teaching Hospital, Benin City, Nigeria \\ *Corresponding author, email:drmerccy@yahoo.com
}

\begin{abstract}
Background: This study was aimed at assessing the level of knowledge, attitude and practice of dental surgeons on human immunodeficiency virus (HIV) and hepatitis B virus (HBV) post-exposure prophylaxis (PEP).

Methods: A descriptive, cross-sectional study was conducted among all the consenting dental surgeons at the University of Benin Teaching Hospital, Benin City, Nigeria, between May and July, 2015. The survey was carried out using a self-administered, anonymous, twenty-five item, and structured questionnaire.

Results: A total of 40 (74.1\%) males and $14(25.9 \%)$ females responded in the study. The majority, 37 (68.5\%), of the dental surgeons had inadequate knowledge about PEP. Majority of the dental surgeons, 44 (81.5\%), had a good attitude towards PEP for HIV/HBV. From the study participants, 52 (96.3\%) agreed on the importance of PEP for HIV/HBV in the work place. A high proportion of the respondents, $47(87.0 \%)$, had been vaccinated against HBV. Among all of the respondents, 25 (46.3\%) were exposed to HIV/HBV risky conditions. Sixteen of the 25 exposed dental surgeons, 16/25 (64.0\%), did not take PEP. Among the respondents who did not take PEP, 15 of those 16 (93.6\%) stated that their reason for not taking PEP was due to fear of stigma and discrimination.

Conclusion: This study shows that knowledge and practice of dental surgeons towards PEP for HIV/HBV is inadequate. A formal PEP training centre with proper guidelines is recommended for dental surgeons.
\end{abstract}

Keywords: attitude, dental surgeons, knowledge, post-exposure prophylaxis, practice

\begin{abstract}
Introduction
Blood-borne pathogens may be transmitted through percutaneous or mucocutaneous exposure to bodily fluids, especially via needle stick injuries (NSIs) and splash injuries. ${ }^{1}$ The average risk of transmission of human immunodeficiency virus (HIV) from a positive source is estimated to be $0.3 \%$ from a single percutaneous exposure and $0.09 \%$ from mucous membrane exposure, ${ }^{2} 6-24 \%$ for hepatitis B virus (HBV) ${ }^{3}$ and $1-10 \%$ for hepatitis $\mathrm{C}$ virus $(\mathrm{HCV}) ., 5$ Since the first documented case of occupational transmission of HIV to a healthcare worker (HCW) in 1984, ${ }^{6} 94$ confirmed and 170 possible cases have been reported world-wide until 1997.7,8 Although the risk of HIV transmission in the dental office is very low, there have been reports of HIV transmission from infected dental surgeon to patient, 9,10 and vice versa. Furthermore, the HIV infection status in the majority of patients is not known at the time of the initial visit, and if known they are less likely to disclose it to the dental surgeon. ${ }^{10,11}$
\end{abstract}

HBV has long been recognised as an occupational risk to healthcare personnel, including healthcare trainees. ${ }^{12,13}$ The virus remains infectious for prolonged periods on environmental surfaces, and is transmissible in the absence of visible blood. ${ }^{12}$ Among HCWs, sero-prevalence of HBV is two to four times higher than that of the general population. . $^{14,15}$ More than $90 \%$ of infected people in the general population live in the developing world. The available data from developing countries show that adherence to the "standard precaution" and adequate documentation of occupational exposures are suboptimal, and knowledge on post-exposure prophylaxis (PEP) among HCWs is poor. ${ }^{16,17}$

Special precautions, however, are recommended for dentistry. ${ }^{18}$ Occupationally acquired infection with HBV and HIV in dental

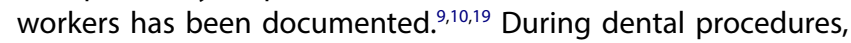
contamination of saliva with blood is predictable, trauma to $\mathrm{HCWs}^{\prime}$ hands is common, and blood spattering may occur. Infection control precautions for dentistry minimise the potential for non-intact skin and mucous membrane contact of dental HCWs to blood-contaminated saliva of patients. ${ }^{18}$ Transmission of HBV in saliva can also occur through breaks in the skin, but experimental transmission of HBV by saliva administered orally has not been accomplished..$^{20}$

According to the World Health Organisation, the exact scale of occupational risk in the health sector is unclear, due in part to the stigma and blame attached to the reporting of sharps injuries and the lack of available post-exposure prophylaxis. ${ }^{21,22} \mathrm{HBV}$ is a well-recognised occupational risk for dental HCWs in an endemic area like Nigeria. ${ }^{19}$ Also, Nigeria ranks among the top three countries with the highest burden of HIV/AIDS, ${ }^{7}$ and as such dental surgeons who are involved in the provision of oral health care are constantly at risk of acquiring HIV and other blood borne pathogens. At a national level the number of health professionals that suffer from sharp injuries remains unknown in Nigeria.? 


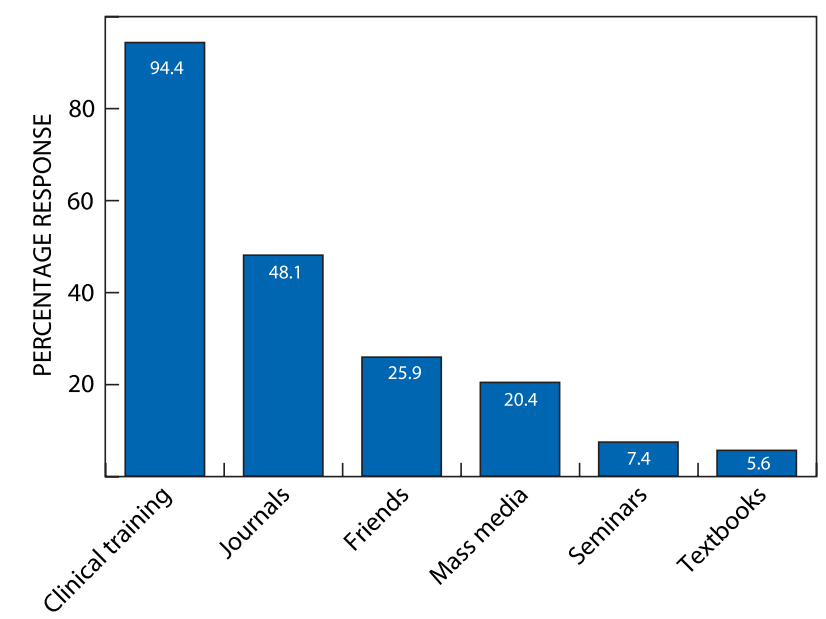

Figure 1: Sources of information about PEP.

Thus, identifying the knowledge, attitude and practice of dental surgeons regarding PEP against blood-borne pathogens may provide baseline data which may then be a useful source for intervention. Therefore, this study is aimed at assessing the level of knowledge, attitude and practice of dental surgeons on HIV and HBV PEP in our tertiary health institution in Nigeria.

\section{Methods}

This was a descriptive, cross-sectional study conducted among all the consenting dental surgeons at the University of Benin Teaching Hospital, Benin City, Nigeria, between May and July, 2015. The study protocol was reviewed and approved by the Research and Ethics Committee of the Hospital.

The survey was carried out using a self-administered, anonymous, twenty-five item, structured questionnaire. Questions were sourced, with some modifications, from a pre-validated questionnaire from a published article. ${ }^{23,24}$

The questionnaire was pretested amongst selected dental surgeons before the study commenced, to identify any problem areas in the questionnaire and to make appropriate alterations, as adjudged necessary. The questionnaire was divided into four broad sections:

\section{Section A}

Questions were close-ended and dealt with sociodemographic variables. The sociodemographic variables included age, gender, marital status, professional status and number of years in practice.

\section{Section B}

This section was made up of nine structured questions. Eight questions were used to assess the general knowledge and one question assessed sources of information of PEP. The questions on knowledge assessed the indications, maximum delay, preferable time, effectiveness, length of time to take PEP, training and guidelines of PEP. All questions in this section were close ended, with instructions to participants to select answers, as appropriate. When respondents correctly answered $\geq 75 \%$ of the eight knowledge questions, they were considered to have adequate knowledge. When $<75 \%$ of the eight knowledge questions were answered correctly, respondents were considered to have inadequate knowledge.

\section{Section C}

This section contained a seven-item question to assess the response of the participants with regard to their attitude towards PEP against blood-borne viral diseases. The questions raised revolved around the importance, behavioural change associated with PEP training, having PEP guidelines in work areas, likelihood of PEP to prevent further infection, giving PEP for all sharps injuries and the belief that PEP is not important if the exposure is not with patient blood of known HIV/HBV. The negative opinions were intermingled with the positive ones to facilitate a wide range of expressions of attitudes. A score of $75 \%$ and above was considered as having a good attitude.

\section{Section D}

This section assessed the practice of dental surgeons towards PEP with a total of nine questions. Issues raised included vaccination against HBV, exposure to HIV/HBV risky conditions, taking PEP after exposure, reasons for not using PEP, reasons for using PEP, time of starting PEP, duration of PEP, completion and reasons for discontinuation of PEP. Respondents who answered positively to more than $75 \%$ of the questions had good practice.

Data from the questionnaires were manually scored, graded, coded, and finally entered into Statistical Package for Social Sciences (SPSS) version 17.0 for data analysis. The results were presented in tables as frequencies and percentages.

\section{Results}

Out of a total of seventy questionnaires distributed to all the dental surgeons in the hospital, 54 were returned duly filled

Table 1: Socio-demographic characteristics of dental surgeons

\begin{tabular}{|c|c|c|}
\hline $\begin{array}{l}\text { Sociodemographic } \\
\text { characteristics }\end{array}$ & Number $(n=54)$ & Percent \% \\
\hline \multicolumn{3}{|c|}{ Age of respondents (years) } \\
\hline $20-30$ & 8 & 14.8 \\
\hline $31-40$ & 27 & 50.0 \\
\hline $41-50$ & 14 & 25.9 \\
\hline $51-60$ & 4 & 7.4 \\
\hline $61-70$ & 1 & 1.9 \\
\hline \multicolumn{3}{|l|}{ Sex } \\
\hline Male & 40 & 74.1 \\
\hline Female & 14 & 25.9 \\
\hline \multicolumn{3}{|l|}{ Marital status } \\
\hline Single & 9 & 16.7 \\
\hline Married & 44 & 81.5 \\
\hline Divorced & 1 & 1.9 \\
\hline \multicolumn{3}{|l|}{ Years of practice } \\
\hline $1-10$ & 30 & 55.6 \\
\hline $11-20$ & 18 & 33.3 \\
\hline $21-30$ & 4 & 7.4 \\
\hline $31-40$ & 2 & 3.7 \\
\hline \multicolumn{3}{|l|}{ Professional status } \\
\hline House-officer & 5 & 9.3 \\
\hline Junior residents & 13 & 24.1 \\
\hline Senior residents & 16 & 29.6 \\
\hline Consultants & 20 & 37.0 \\
\hline
\end{tabular}


Table 2: Knowledge of dental surgeons about PEP

\begin{tabular}{|c|c|c|}
\hline Question & Response & $\begin{array}{c}\text { Frequency, } \\
n(\%)\end{array}$ \\
\hline \multirow{2}{*}{$\begin{array}{l}\text { Have you heard about } \\
\text { of PEP? }\end{array}$} & Yes & $53(98.1)$ \\
\hline & No & $1(1.9)$ \\
\hline \multirow{6}{*}{$\begin{array}{l}\text { Source of information } \\
\text { about PEPa }\end{array}$} & Clinical training & $51(94.4)$ \\
\hline & Mass media & $11(20.4)$ \\
\hline & Journals & $26(48.1)$ \\
\hline & Friends & $14(25.9)$ \\
\hline & Seminars & $4(7.4)$ \\
\hline & Textbooks & $3(5.6)$ \\
\hline \multirow[t]{4}{*}{$\begin{array}{l}\text { When do you think PEP } \\
\text { should be indicated? }\end{array}$} & $\begin{array}{l}\text { When the source patient is at } \\
\text { high risk for HIV/HBV }\end{array}$ & $40(74.1)$ \\
\hline & $\begin{array}{l}\text { When the patient is known to } \\
\text { be HIV/HBV positive }\end{array}$ & $40(74.1)$ \\
\hline & $\begin{array}{l}\text { When the HIV/HBV status of } \\
\text { the source is unknown }\end{array}$ & $31(57.4)$ \\
\hline & $\begin{array}{l}\text { For any needle stick injury in } \\
\text { the workplace }\end{array}$ & $36(66.7)$ \\
\hline \multirow{5}{*}{$\begin{array}{l}\text { What is the maximum } \\
\text { delay for PEP? }\end{array}$} & Within an hour & $11(20.4)$ \\
\hline & $12 \mathrm{~h}$ & $11(20.4)$ \\
\hline & $24 \mathrm{~h}$ & $17(31.5)$ \\
\hline & $48 \mathrm{~h}$ & $2(3.7)$ \\
\hline & $72 \mathrm{~h}$ & $10(18.5)$ \\
\hline \multirow{4}{*}{$\begin{array}{l}\text { What is the preferable time } \\
\text { to take PEP? }\end{array}$} & Within an hour of exposure & $48(88.9)$ \\
\hline & After $6 \mathrm{~h}$ of exposure & $3(5.6)$ \\
\hline & After $12 \mathrm{~h}$ of exposure & $0(0.0)$ \\
\hline & After $72 \mathrm{~h}$ of exposure & $2(3.7)$ \\
\hline \multirow{5}{*}{$\begin{array}{l}\text { What is the effectiveness } \\
\text { of PEP? }\end{array}$} & $20-30 \%$ & $0(0.0)$ \\
\hline & $30-50 \%$ & $5(9.3)$ \\
\hline & $60-70 \%$ & $24(44.4)$ \\
\hline & $80-100 \%$ & $18(33.3)$ \\
\hline & $100 \%$ & $1(1.9)$ \\
\hline \multirow{4}{*}{$\begin{array}{l}\text { What is the length of time } \\
\text { to take PEP? }\end{array}$} & For 28 days & $34(63.0)$ \\
\hline & For 40 days & $1(1.9)$ \\
\hline & For 6 months & $10(18.5)$ \\
\hline & For life & $0(0.0)$ \\
\hline \multirow{2}{*}{$\begin{array}{l}\text { Have you attended any } \\
\text { training about PEP? }\end{array}$} & Yes & $12(22.2)$ \\
\hline & No & $40(74.1)$ \\
\hline \multirow{2}{*}{$\begin{array}{l}\text { Do you know about the } \\
\text { PEP guidelines? }\end{array}$} & Yes & $32(59.3)$ \\
\hline & No & $17(31.5)$ \\
\hline
\end{tabular}

${ }^{a}$ multiple answers allowed.

giving a response rate of $77.1 \%$. A total of $40(74.1 \%)$ males and 14 (25.9\%) females responded in the study. Most of the dental surgeons, $27(50.0 \%)$, were in the age group of 31 to 40 years. Forty-four (81.5\%) of the dental surgeons were married. About 20 $(37.0 \%)$ were consultants and $16(29.6 \%)$ of the respondents were senior resident doctors. Regarding years of practice of dental surgeons, $30(55.6 \%)$ had practised for less than 10 years, 18 (33.3\%) for $11-20$ years, and 6 (11.1\%) for over 20 years (Table 1 ).

\section{Knowledge of dental surgeons regarding PEP}

The majority, 37 (68.5\%), of the dental surgeons had inadequate knowledge about PEP for blood-borne viral infections. Most of the respondents, 51 (94.4\%), have heard about PEP from clinical
Table 3: Attitude of dental surgeons about PEP

\begin{tabular}{|c|c|c|}
\hline Questions & Responses & $\begin{array}{l}\text { Frequency, } \\
\quad n(\%)\end{array}$ \\
\hline \multirow[t]{3}{*}{ Do you think PEP is important? } & Yes & $52(96.3)$ \\
\hline & No & $0(0.0)$ \\
\hline & Not sure & $1(1.9)$ \\
\hline \multirow{3}{*}{$\begin{array}{l}\text { Do you believe that training of PEP is impor- } \\
\text { tant for a behavioural change? }\end{array}$} & Agree & $48(88.9)$ \\
\hline & Disagree & $0(0.0)$ \\
\hline & Neutral & $5(9.3)$ \\
\hline \multirow{3}{*}{$\begin{array}{l}\text { Do you think there should be a PEP guideline } \\
\text { in the work place? }\end{array}$} & Agree & $38(70.4)$ \\
\hline & $\begin{array}{l}\text { Strongly } \\
\text { agree }\end{array}$ & $16(29.6)$ \\
\hline & Disagree & $0(0.0)$ \\
\hline \multirow{3}{*}{$\begin{array}{l}\text { Do you believe PEP reduces the likelihood of } \\
\text { being HIV positive? }\end{array}$} & Yes & $50(92.6)$ \\
\hline & No & $1(1.9)$ \\
\hline & Not sure & $3(5.6)$ \\
\hline \multirow{3}{*}{$\begin{array}{l}\text { Do you believe PEP helps to prevent further } \\
\text { infection? }\end{array}$} & Agree & $35(64.8)$ \\
\hline & $\begin{array}{l}\text { Partially } \\
\text { agree }\end{array}$ & $5(9.6)$ \\
\hline & Disagree & $12(22.2)$ \\
\hline \multirow{3}{*}{$\begin{array}{l}\text { What is your opinion on the saying that PEP } \\
\text { is indicated for any type of sharp injuries? }\end{array}$} & Agree & $28(51.9)$ \\
\hline & Disagree & $14(25.9)$ \\
\hline & Not sure & $12(22.2)$ \\
\hline \multirow{3}{*}{$\begin{array}{l}\text { What is your opinion on the belief that PEP } \\
\text { is not important if the exposure is not with } \\
\text { patient blood of known HIV/HBV positivity? }\end{array}$} & Agree & $11(20.4)$ \\
\hline & Disagree & $35(64.8)$ \\
\hline & Not sure & $6(11.1)$ \\
\hline
\end{tabular}

training. (Figure 1) Forty-eight (88.9\%) of the respondents knew when to initiate PEP, however $10(18.5 \%)$ of the respondents knew the maximum delay for PEP. Eighteen (33.3\%) of the respondents knew about the efficiency of PEP, and 34 (63.0\%) knew how long an exposed individual should be on PEP. Regarding attending training about PEP, 12 (22.2\%) respondents have had some training on PEP (Table 2 ).

\section{Attitude of dental surgeons regarding PEP}

Majority of the dental surgeons, 44 (81.5\%), had a good attitude towards PEP for HIV/HBV. Fifty-two respondents (96.3\%) acknowledged the importance of PEP for HIV/HBV, and 54 $(100.0 \%)$ knew about the availability of PEP guidelines in the work place. About 48 (88.9\%) of the respondents believed that training on PEP was important for a behavioural change. Majority, 50 (92.6\%), of the respondents believed that PEP reduces the likelihood of being HIV-positive after exposure, and 35 (64.8\%) of the respondents agreed that PEP prevents further infection. When asked their opinion on the indication of PEP for any type of sharps injuries, 28 (51.9\%) agreed, 14 (25.9\%) disagreed and 12 (22.2\%) were unsure (Table 3 ).

\section{Practice status of the dental surgeons towards PEP for HIV/HBV}

A high proportion of the respondents, 47 (87.0\%), had been vaccinated against HBV. Among all of the respondents, 25 (46.3\%) were exposed to HIV/HBV risky conditions. Of the exposed dental surgeons, 9 of the 25 (36.0\%) took PEP, whilst 16 of the 25 (64.0\%) did not take PEP. Among the respondents who did not take PEP, 15 of the 16 (93.6\%) stated that their reason for not taking PEP was fear of stigmatisation and discrimination, 6 of the $16(37.0 \%)$ stated that the patient tested negative, and 4 of 
Table 4: Practice of PEP among dental surgeons

\begin{tabular}{|c|c|c|}
\hline Questions & Responses & $\begin{array}{l}\text { Frequency, } \\
\quad n(\%)\end{array}$ \\
\hline \multirow{2}{*}{$\begin{array}{l}\text { Have you been vaccinat- } \\
\text { ed against Hepatitis B? }\end{array}$} & Yes & $47(87.0)$ \\
\hline & No & $6(11.1)$ \\
\hline \multirow{3}{*}{$\begin{array}{l}\text { Ever been exposed to } \\
\text { HIV/HBV risky conditions }{ }^{b}\end{array}$} & Yes & $25(46.3)$ \\
\hline & No & $23(42.6)$ \\
\hline & I do not remember & $6(11.1)$ \\
\hline \multirow{2}{*}{$\begin{array}{l}\text { Did you take PEP after } \\
\text { exposure? }\end{array}$} & Yes & $9(36.0)$ \\
\hline & No & $16(64.0)$ \\
\hline \multirow[t]{6}{*}{$\begin{array}{l}\text { Reasons for not taking } \\
\text { PEPa }\end{array}$} & $\begin{array}{l}\text { Unaware of the existence of PEP } \\
\text { service and protocol }\end{array}$ & $4(25.0)$ \\
\hline & $\begin{array}{l}\text { Lack of understanding the value } \\
\text { of reporting exposures }\end{array}$ & $3(18.6)$ \\
\hline & $\begin{array}{l}\text { Fear of stigma and discrimi- } \\
\text { nation }\end{array}$ & $15(93.6)$ \\
\hline & $\begin{array}{l}\text { Lack of support and encourage- } \\
\text { ment to report }\end{array}$ & $1(6.3)$ \\
\hline & PEP service is unavailable & $3(18.6)$ \\
\hline & Client tested negative & $6(37.5)$ \\
\hline \multirow[t]{4}{*}{$\begin{array}{l}\text { Reasons respondents } \\
\text { took PEP after exposure }\end{array}$} & $\begin{array}{l}\text { Exposure to blood from known } \\
\text { HIV/HBV positive patients }\end{array}$ & $0(0.0)$ \\
\hline & $\begin{array}{l}\text { Exposure to blood from patients } \\
\text { with unknown HIV/HBV status }\end{array}$ & $9(100.0)$ \\
\hline & Injury from a sharp object & $5(55.6)$ \\
\hline & $\begin{array}{l}\text { Contact with patient's body } \\
\text { fluids }\end{array}$ & $4(44.4)$ \\
\hline \multirow{4}{*}{$\begin{array}{l}\text { What time did you start } \\
\text { taking PEP? }\end{array}$} & Within $1 \mathrm{~h}$ & $2(22.2)$ \\
\hline & After $2-6 \mathrm{~h}$ of exposure & $7(77.8)$ \\
\hline & After 6-10 $\mathrm{h}$ of exposure & $0(0.0)$ \\
\hline & After $72 \mathrm{~h}$ & $0(0.0)$ \\
\hline \multirow{4}{*}{$\begin{array}{l}\text { A period of time that a } \\
\text { respondent took PEP? }\end{array}$} & 3 days & $3(33.3)$ \\
\hline & 15 days & $1(11.1)$ \\
\hline & 28 days & $4(44.4)$ \\
\hline & 48 days & $1(11.1)$ \\
\hline \multirow{2}{*}{$\begin{array}{l}\text { Did you complete the } \\
\text { prescribed drug of PEP? }\end{array}$} & Yes & $4(44.4)$ \\
\hline & No & $5(55.6)$ \\
\hline \multirow{4}{*}{$\begin{array}{l}\text { Reason for discontinua- } \\
\text { tion of the drug }\end{array}$} & Fear of adverse effects & $4(80.0)$ \\
\hline & Assuming that it was enough & $2(40.0)$ \\
\hline & $\begin{array}{l}\text { Assuming that the drug was not } \\
\text { effective }\end{array}$ & $1(20.0)$ \\
\hline & Client tested negative & $2(40.0)$ \\
\hline
\end{tabular}

aultiple answers allowed.

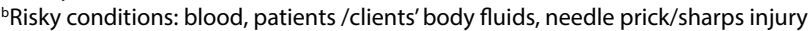
at work place.

the 16 (25.0\%) were unaware of the existence of PEP services and PEP protocol in the hospital. Among the respondents who took PEP, 9 of the 9 (100.0\%) stated that they took PEP due to their exposure to patients with unknown HIV/HBV status, 5 of the 9 (55.6\%) had injury from sharp objects, and 4 of the 9 (44.4\%) had contact with patient's body fluid. Among the dental surgeons that took PEP, 2 of the 9 (22.2\%) correctly started taking PEP at the exact initiation time, and 4 of the 9 (44.4\%) completed the PEP course correctly. The reason for the discontinuation of PEP was found to be a fear of adverse effects among 4 of the 5 (80.0\%) respondents (Table 4).

\section{Discussion}

HIV and HBV constitute a serious public health concern, and occupational exposure of $\mathrm{HCWs}$ to these viruses poses a threat to healthcare delivery systems in resource-limited settings. Standard precautions have been advocated by the Centre for Disease Control (CDC, USA) as a means to reduce occupational exposures to HIV and other blood-borne pathogens. ${ }^{18}$ In spite of the precautions, occupational exposure still occurs. Therefore, studies relating to knowledge, attitude and practices of HCWs are vital as they help to inform policy formulations on occupational PEPs against blood-borne pathogens, such as HIV and HBV.

This study shows that $98.1 \%$ of the participants have heard about PEP for HIV. This finding is higher than similar studies conducted in a tertiary hospital in Nigeria, ${ }^{7}$ Gondar in Ethiopia ${ }^{10}$ and in India. ${ }^{21}$ In the institution where the present study was done, there is an infection control unit where incidences of occupational exposures are reported and PEP instituted. But, updates or seminars on standard precautions and PEP are not routinely done for the HCWs. Therefore, the staff members depend on clinical teaching $(98.1 \%)$ or journals $(48.1 \%)$ to learn about PEP.

In this study, $88.9 \%$ of respondents had knowledge of the best time for the initiation of PEP, which is higher compared to that reported by Mathewos et al,. among HCWs, ${ }^{23}$ Kasat et al., ${ }^{10}$ among postgraduate dental surgeons, Chacko and Isaac ${ }^{25}$ among medical interns, and Khan et al., ${ }^{26}$ among medical staff, but less than that reported by Agaba et al., ${ }^{7}$ in family physicians. The difference might be due to the difference on the level of awareness among the different study populations. The maximum benefit of PEP is obtained by commencing prophylaxis within the first hour of exposure, although it may be delayed to a maximum of 72 hours, after which it is less effective in preventing infection. ${ }^{17}$ The present study shows that $63.0 \%$ knew the length of time to take PEP. This value is low compared to previous reports from Nigeria $^{7}$ and Ethiopia, ${ }^{23}$ but higher than the report from a study among HCWs in Indian. ${ }^{27}$ This study shows that only $22.2 \%$ of the participants have attended any training about PEP. This may be due to the fact that training or seminars on PEP and standard precautions are not frequently carried out for the HCWs in the institution. This is lower than the Mathewos et al. ${ }^{23}$ report from Ethiopia, but higher than the report by Shivaprakash et al., ${ }^{27}$ among dental surgeons in India. The majority of the dental surgeons in the present study had inadequate knowledge about PEP for blood-borne viral infections, which is lower than the finding of Tebeje and Hailu ${ }^{24}$ in south-west Ethiopia, but slightly higher than what is reported in a Zimbabwean study. ${ }^{28}$

The dental surgeons exhibited a good attitude towards PEP for HIV/HBV. Over $95 \%$ of the participants agreed on the importance of PEP for HIV/HBV and the availability of PEP guidelines in work place. This finding was comparable to that reported by Mathewos et al. $^{23}$ but higher than the $61 \%$ reported from a study in Uganda. ${ }^{29}$

Although this study shows that majority of the dental surgeons were vaccinated against $\mathrm{HBV}$, which is comparable to the reports from previous studies, ${ }^{30,31}$ our hospital does not maintain a policy on vaccination of HCWs against HBV. The available medical literature does not adequately address the issue of the HCW's knowledge-base on modes of transmission and PEP for HBV and HCV. ${ }^{30}$ The dental surgeons exposed to HIV/HBV in the work place in this study $(46.3 \%)$ is less than that reported in a study conducted in southern India (74.5\%). ${ }^{32}$ However, this is higher 
than the reports from Ethiopia $(33.8 \%)^{23}$ and Italy (11.3\%)..$^{33}$ Generally, the difference between the present study and the others might be due to the difference in the study population. Although $36.0 \%$ of the exposed respondents took PEP in this study, $64.0 \%$ did not take PEP after exposure, even with the availability of PEP at the infection control unit of the hospital. Some of the reasons cited by the respondents for not partaking of the PEP service (64\%) included: fear of stigmatisation and discrimination; lack of awareness of the existence of the PEP service and protocol; and, lack of understanding of the value of reporting exposures. Comparatively, an alarmingly high proportion of Nigerian surgeons in another centre took no action when they were exposed..$^{34} \mathrm{~A}$ study of European medical students found that few students did not report needle stick injuries, ${ }^{35}$ and only $18 \%$ of London, England, doctors sought advice regarding PEP despite over three-quarters of doctor reporting occupational injury. ${ }^{36}$ The reason for the discontinuation of PEP was found to be fear of adverse effects among the respondents. This finding was in agreement with another study conducted in Dar es Salaam, Tanzania, in which they showed that many respondents failed to use PEP for the full length of the time prescribed. ${ }^{37}$ However, studies conducted in Ethiopia and Gujarat, India, showed that their respondents had better practice in this regard ${ }^{23,38}$ than our study participants. This finding tends to reinforce the belief that the practice of PEP for HIV/HBV in the study area needs improvement.

\section{Conclusion}

In conclusion, the study revealed that the knowledge and practice of dental surgeons about PEP against blood-borne viral infections was inadequate. Majority of the dental surgeons were exposed to the risk of HIV/HBV, and only few of them used PEP due to fear of stigmatisation and discrimination. Availability of a formal PEP training centre with proper guidelines is recommended to enhance the utilisation of PEP amongst dental surgeons.

Authors' contribution - M Okoh conceived the idea, carried out data collection, conducted statistical analysis, and drafted the manuscript. BD Saheeb contributed to the study design and statistical analysis, and provided critical review of the manuscript. Both authors reviewed and approved the final manuscript.

Acknowledgements - We would like to acknowledge the School of Dentistry, University of Benin Annual Scientific Conference, Benin City, Nigeria (August 26th to 27th, 2015) for granting us the opportunity to carry out an oral presentation of this paper at the Conference.

Competing interests - The authors declare no competing interests.

\section{References}

1. Sepkowitz KA. Occupationally acquired infections in health care workers: part I. Ann Intern Med. 1996;125:826-34.

2. Panlilio AL, Cardo DM, Grohskopf LA, et al. Updated U.S. Public Health Service guidelines for the management of occupational exposures to HIV and recommendations for post exposure prophylaxis. MMWR Recommendations and reports. 2005;54:1-17.

3. Shapiro CN. Occupational risk of infection with hepatitis $B$ and hepatitis C virus. Surg Clin North Am. 1995;75:1047-56.

4. Yazdanpanah Y, De Carli G, Migueres B. Risk factors for hepatitis C virus transmission to health care workers after occupational exposure: a european case-control study. Clin Inf Dis. 2005;41:1423-30.

5. Vaid N, Langan KM, Maude RJ. Post-exposure prophylaxis in resourcepoor settings:review and recommendations for pre-departure risk assessment and planning for expatriate healthcare workers. TMIH. 2013;18:588-95.
6. Anon. Needlestick transmission of HTL-VIII from a patient infected in Africa. Lancet. 1984;2:1376-7.

7. Agaba PA, Agaba El, Akanbi MO, Daniyam CA, Ocheke AN, Okeke EN Awareness and knowledge of human immunodeficiency virus post exposure prophylaxis among Nigerian Family Physicians. Niger Med J. 2012;53:155-60.

8. Ippolito G, Puro V, Heptonstall J, Jagger J, De Carli G, Petrosillo N. Occupational human immunodeficiency virus infection in health care workers: worldwide cases through september 1997. Clin Infect Dis. 1999;28:365-83.

9. Ciesielski C, Marianos D, Ou CY, Dumbaugh R, Witte J, Berkelman R, et al. Transmission of human immunodeficiency virus in a dental practice. Ann Intern Med. 1992;116:798-805.

10. Kasat VO, Saluja H, Ladda R, Sachdeva S, Somasundaram KV, Gupta A. Knowledge, attitude and practices toward post exposure prophylaxis for human immunodeficiency virus among dental students in India. Ann Med Health Sci Res. 2014;4:543-8.

11. Perry SW, Moffatt M Jr, Card CA, et al. Self-disclosure of HIV infection to dentists and physicians. J Am Dent Assoc. 1993;124:51-4.

12. US Public Health Service. Updated U.S. Public Health Service guidelines for the management of occupational exposures to HBV $\mathrm{HCV}$, and HIV and recommendations for postexposure prophylaxis. MMWR. 2001;29:50(No. RR-11).

13. Rosenberg JL, Jones DP, Lipitz LR, Kirsner JB. Viral hepatitis: an occupational hazard to surgeons. JAMA. 1973;223:395-400.

14. Sepkowitz KA. Occupationally acquired infections in health care workers: part II. Ann Intern Med 1996;125:917-28.

15. Lewis TL, Alter HJ, Chalmers TC. A comparison of the frequency of hepatitis-B antigen and antibody in hospital and nonhospital personnel. N Engl J Med. 1973;289:647-51.

16. Gounden YP, Moodley J. Exposure to human immunodeficiency virus among healthcare workers in South Africa. Int J Gynaecol Obstet. 2000;69:265-70.

17. Chogle NL, Chogle MN, Divatia JV, Dasgupta D. Awareness of postexposure prophylaxis guidelines against occupational exposure to HIV in a Mumbai hospital. Natl Med J India. 2002;15:69-72.

18. Centers for Disease Control. Perspectives in disease prevention and health promotion update: universal precautions for prevention of transmission of human immunodeficiency virus, hepatitis B virus, and other blood borne pathogens in health-care settings. MMWR. 1988:37;377-88

19. Sofola OO, Uti OG. Hepatitis B virus infection and prevention in the dental clinic: knowledge and factors determining vaccine uptake in a Nigerian dental teaching hospital. Nig Q J Hosp Med. 2008;18(3):145-8.

20. Scott RM, Snitbhan R, Bancroft WH, Alter HJ, Tingpalapong M. Experimental transmission of hepatitis B virus by semen and saliva. J Infect Dis. 1980;142(1):67-71.

21. Sagoe-Moses C, Pearson RD, Perry J, Jagger J. Risks to health care workers in developing countries. N Engl J Med 2001;345:538-41.

22. Sendo EG. Assessment of level of knowledge and practice of nursing and midwifery students on HIV post exposure prophylaxis in Hawassa University, Ethiopia. J HIV Clin Scientific Res. 2014;1:101-5.

23. Mathewos B, Birhan W, Kinfe S, Boru M, Tiruneh G, Addis Z, et al. Assessment of knowledge, attitude and practice towards post exposure prophylaxis for HIV among health care workers in Gondar, North West Ethiopia. BMC Public Health 2013;13:508. doi:10.1186/1471-2458-13-508.

24. Tebeje B, Hailu C. Assessment of HIV post-exposure prophylaxis use among health workers of governmental health institutions in Jimma Zone, Oromiya Region, Southwest Ethiopia.. Ethiop J Health Sci. 2010;20:55-64.

25. Chacko J, Isaac R. Percutaneous injuries among medical interns and their knowledge and practice of post-exposure prophylaxis for HIV. Indian J Public Health 2007;51:127-9.

26. Khan AZ, Duncan KM, Escofet X, Miles WF. Do we need to improve awareness about HIV post exposure prophylaxis? Ann R Coll Surg Engl 2002;84:72-3.

27. Shivaprakash G, Suvarna P, Pallavi LC. Assessment of knowledge of post exposure prophylaxis (PEP) for HIV among healthcare workers (HCWS) at a tertiary care hospital. World J Pharm Sci. 2015:4:1091-9.

28. Monera T, Ncube P. Assessment of knowledge, attitude and practice of health care workers on occupational HIV post exposure prophylaxis at Zimbabwean referral hospital. J Int AIDS Soc. 2012;15:23-9. 
29. Alenyo R, Fualal J, Jombwe JJ. Knowledge, attitude and practices of staffs toward postexposure prophylaxis for HIV infection at Mulago hospital in Uganda. East Cent Afr J Surg 2009;14:99-102.

30. Baheti AD, Tullu MS, Lahiri KR. Awareness of health care workers regarding prophylaxis for prevention of transmission of blood-borne viral infections in occupational exposures. Al Ameen J Med Sci. 2010;3:79-83.

31. Wig N. HIV: awareness of management of occupational exposure in health care workers. Indian J Med Sci 2003;57:192-8.

32. Tetali S, Choudhury PL. Occupational exposure to sharps and splash: risk among health care providers in three tertiary care hospitals in South India. Indian J Occup Environ Med. 2006;10:35-40.

33. Bandolier E. Occupational exposure to hospital employees in Italian hospitals over 5.5 years. London: AstraZeneca group; 2003.

34. Nwankwo TO, Aniebue UU. Percutaneous injuries and accidental blood exposure in surgical residents: awareness and use of prophylaxis in relation to HIV. Nig J clin. pract. 2011;14:34-7.
35. Salzer HJ, Hoenigl M, Kessler HH. Lack of risk awareness and reporting behavior towards HIV infection through needlestick injury among European medical students. Intl J Hygiene Environ Health. 2011;214:407-10.

36. Chen MY, Fox EF, Rogers CA. Post-exposure prophylaxis for human immunodeficiency virus: knowledge and experience of junior doctors. Sex Transm Inf. 2001;77:444-5.

37. Chagani MM, Manji KP, Manji MP, Sheriff FG. Healthcare workers' knowledge, attitudes, practices on post exposure prophylaxis for HIV in Dar es Salaam. Tanzania Med J. 2011;25:33-8.

38. Shevkani M, Kavina B, Kumar P, Purohit H, Nihalani U, Shah A. An overview of post exposure prophylaxis for HIV in health care personals: Gujarat scenario. Indian j sex transm Dis. 2011;32:9-13.

Received: 23-10-2015 Accepted: 30-05-2016 